\title{
Double Exposures: Future Water Security across Urban Southeast Asia
}

\author{
Theresa E. Lorenzo * and Ann P. Kinzig \\ School of Life Sciences, Arizona State University, Tempe, AZ 85202, USA; Ann.Kinzig@asu.edu \\ * Correspondence: tlorenzo@asu.edu
}

Received: 16 November 2019; Accepted: 24 December 2019; Published: 30 December 2019

\begin{abstract}
Southeast Asia is one of the most dynamic regions in the world in terms of economic growth and urbanization. At the same time, the region is also prone to multiple hydro-meteorological disasters, which are projected to be intensified by climate change. This paper analyzes the combined effect of economic development and climate change on the future water security of middle-income Southeast Asian countries using the double exposure framework, focusing on the effects in urban areas. A review of the existing literature reveals unequal water security outcomes across the region as a result of combined climate, economic, and urbanization pressures. The water supply and sanitation infrastructure of upper-middle-income Southeast Asian countries are vulnerable to damage from intensified disasters, potentially decreasing both immediate and longer-term water quality. In lower-middle-income countries, the water quality will be the more important water security challenge in the short-term as opposed to water quantity, mainly due to the fast growth of industries. Lower-middle-income countries, though less vulnerable to disasters, will still have lower future water security compared to upper-middle-income countries, as they have less capacity to address water quality and quantity challenges brought about by both industrial growth and urbanization. Across the region, future water quantity and quality challenges may result in slower economic and urban growth if not planned adequately.
\end{abstract}

Keywords: water security; Southeast Asia; sustainable development; multiple exposures; double exposures; sustainable urban water management

\section{Introduction}

\subsection{Background}

Southeast Asia is one of the fastest-growing regions in the world in terms of both economy and population, with urbanization expected to continue at a high pace in the coming years [1]. Hydro-meteorological disasters, such as floods and cyclones are prevalent in this region, which is naturally disaster-prone [2]. Climate change is projected to intensify these disasters and cause changes in precipitation patterns further, both of which will further add to water stress. At the same time, Southeast Asia is industrializing, with industry and service playing an increasingly important role in the region's economies as compared to agriculture, and some countries have set targets of becoming developed countries within 30 years [3,4].

Both climate change and future development will certainly impact future water security in the region. Water security is defined by the United Nations (UN) as "The capacity of a population to safeguard sustainable access to adequate quantities of and acceptable quality water for sustaining livelihoods, human well-being, and socio-economic development, for ensuring the protection against water-borne pollution and water-related disasters, and for preserving ecosystems in a climate of peace and political stability" [5]. Although the impact of climate change on water security in the region has 
been covered extensively [6-8], the impact of future economic development on water security has not been explored in as much detail. Economic water security in the region has been measured as the productivity of economic sectors as compared to their water use through the National Water Security Index [9]. This index, however, does not address the variation in the quantity and quality of water inputs needed to sustain the economic growth of different countries, nor how the wastewater output of different economic sectors can affect water quality. As the economies of countries across the region are composed of different types of industries and services, their water input needs and wastewater outputs will also vary accordingly, with some economic sectors and industry types considered as more polluting than others. The water security implications of increasing urbanization across the region have also been discussed, but have not been placed in the greater context of economic development $[9,10]$. As water security in Southeast Asia is affected by the simultaneous impacts of both climate change and economic development, there is a need to understand the probable water security outcomes and changes in the context that may arise from the combination of the two phenomena.

The combined effect of climate change and economic development on water security will be analyzed in this paper using the double exposure framework, which is used to examine the interactions between global environmental change and globalization [11]. Specifically, this paper will focus on outcome double exposure, studying how the combination of environmental and global change phenomena can exacerbate existing inequalities across the region, and context double exposure, where the combination of the two phenomena can increase vulnerability to different shocks and stresses. The inclusion of multiple stressors, particularly socio-economic factors, in long-term government planning is needed to ensure effective future climate adaptation and sustainable urban futures [12]. The messages of the double exposure framework have been incorporated in water security analyses at different scales and in different contexts, such as the construction of an index identifying specific groups vulnerable to both climate change and water conflict in Chad [13], and in studies examining water governance in the USA [14], as well as in India [15]. In Southeast Asia specifically, the double exposure framework has been mostly used in single countries at the household and community scale, for example, examining seasonal water insecurity [16] and the vulnerability of coastal communities to multiple stressors [17]. The futures of selected coastal megacities in the region have also been compared using the double exposure framework [18]. However, to the best of the authors' knowledge, this framework has not yet been applied in a broad cross-country analysis throughout the region.

\subsection{Methods}

This article applies the double exposure framework to middle-income countries in Southeast Asia as defined by the World Bank [19] through the analysis of existing literature and broad socio-economic data. This paper draws on both peer-reviewed studies and grey literature sources. The major types of literature reviewed include (a) economic reports from regional and international development agencies; (b) reports on climate change and water resources from the same agencies as (a); (c) socio-economic factbooks and databases published by national, regional, and international agencies; and (d) peer-reviewed journals. The primary database consulted for the peer-reviewed studies was the Web of Science, accompanied by hand-searching of relevant studies on Google Scholar. The authors conducted a search of grey literature through three methods: a keyword search using both the Web of Science and the Google search engine, searching the reference list of relevant peer-reviewed articles, and searching for published reports from key international development agencies that conduct research in the field of water security, climate change, and economic development throughout Southeast Asia. The three main development agencies doing work in the region that touched on one or multiple of these fields, as identified by the authors, were the World Bank, Asian Development Bank, and UN-Water. The authors did not enforce strict dates of coverage during their literature search, but focused on studies from 2000 until the present, particularly those conducted in the last decade.

In this paper, both climate and economic development trends resulting from globalization and their impacts on water security on the region as a whole will first be discussed separately, after which 
the impacts resulting from their combination will be analyzed in terms of outcome and context double exposure. This article will focus on the "sustaining livelihoods, human well-being, and socio-economic development" aspects of water security. Through a qualitative cross-country comparative analysis of past trends and future outlooks in the realms of climate change and economic development across Southeast Asia, this review ultimately aims to identify the areas in the region which are most likely to experience the strongest water security stress in the future and discuss the reasons leading to this future stress. Both climate change and socio-economic development stresses should be analyzed in order to adequately plan for not only climate change adaptation, but also for sustainable future urban growth.

\section{Review of Water Security Drivers across Southeast Asia}

\subsection{Trends and Outlook on Economic Growth}

Out of the Southeast Asian countries, Cambodia, Lao PDR, Myanmar, Indonesia, the Philippines, and Vietnam are considered lower-middle (LM) income countries, while Thailand and Malaysia are considered upper-middle (UM) income countries [19]. The economies of the first three countries, were upgraded to a lower-middle-income designation from low income during the past decade, namely 2016 for Cambodia [20], 2011 for Lao People's Democratic Republic [21], and 2015 for Myanmar [22], while the other countries' economies are considered more established. Throughout this paper, Cambodia, Lao PDR, and Myanmar will be collectively referred to as LM, with the remaining countries of Indonesia, the Philippines, Vietnam, Malaysia, and Thailand referred to as UM.

Over the period of 2010-2018, agriculture as a percentage of GDP declined while services as a percentage of GDP rose in all middle income Southeast Asian countries considered save for Lao PDR (Table 1). Since 2010, LM countries are experiencing fast growth in both services (Services refers to categories G-U as defined by the United Nations 23, some of which are wholesale and retail trade, transportation and storage, food and accommodation, information and communication, financial and insurance, real estate, professional, scientific, and technical activities, etc.) and industry (Industry refers to categories B-F defined by the United Nations [23], namely mining and quarrying, manufacturing, electricity, gas, steam, and air-conditioning supply, water supply, water management, and remediation activities, and construction) (Table 1), while the economic expansion of UM countries is mostly in the services sector.

Table 1. Composition of Southeast Asian middle-income-country Gross Domestic Product for 2010 and 2018. Data compiled by the authors from the World Bank [24].

\begin{tabular}{|c|c|c|c|c|c|c|c|c|}
\hline \multirow{3}{*}{ Country } & \multirow{2}{*}{\multicolumn{2}{|c|}{$\begin{array}{c}\text { Agriculture } \\
\% \text { of GDP }\end{array}$}} & \multirow{2}{*}{\multicolumn{2}{|c|}{$\begin{array}{c}\text { Industry } \\
\% \text { of GDP }\end{array}$}} & \multirow{2}{*}{\multicolumn{2}{|c|}{$\begin{array}{c}\text { Manufacturing }^{1} \\
\% \text { of GDP }\end{array}$}} & \multirow{2}{*}{\multicolumn{2}{|c|}{$\begin{array}{c}\text { Services } \\
\% \text { of GDP }\end{array}$}} \\
\hline & & & & & & & & \\
\hline & 2010 & 2018 & 2010 & 2018 & 2010 & 2018 & 2010 & 2018 \\
\hline \multicolumn{9}{|l|}{ LM } \\
\hline Cambodia & 34.0 & 22.0 & 22.0 & 32.0 & 15.0 & 16.0 & 38.3 & 39.5 \\
\hline Lao PDR & 33.0 & 26.0 & 30.0 & 32.0 & 11.0 & 7.0 & 43.6 & 41.6 \\
\hline Myanmar & 37.0 & 25.0 & 26.0 & 32.0 & 20.0 & 24.0 & 36.7 & 43.2 \\
\hline \multicolumn{9}{|l|}{ UM } \\
\hline Indonesia & 14.0 & 13.0 & 43.0 & 40.0 & 22.0 & 20.0 & 40.7 & 43.4 \\
\hline Malaysia & 10.0 & 8.0 & 40.0 & 39.0 & 23.0 & 22.0 & 48.5 & 52 \\
\hline Thailand & 11.0 & 8.0 & 40.0 & 35.0 & 31.0 & 27.0 & 49.5 & 56.9 \\
\hline Philippines & 12.0 & 9.0 & 33.0 & 31.0 & 21.0 & 19.0 & 55.1 & 60 \\
\hline Vietnam & 18.0 & 15.0 & 32.0 & 34.0 & 13.0 & 16.0 & 36.9 & 41.2 \\
\hline
\end{tabular}

${ }^{1}$ Manufacturing is calculated as part of Industry Gross Domestic Product (GDP).

The economies of countries in LM and UM countries differ in terms of the growth of industry, as the former group generally registered an increase in the percentage of industry and manufacturing (save for Lao PDR) as part of their Gross Domestic Product(GDP), while the share of industry in the 
GDP of UM countries declined while that of services increased. The extractive industries of timber and mining are high-value industries in both Lao PDR and Myanmar, whereas in UM countries, although extractive industries still play a role, their economies are more diversified in terms of the type of goods that are produced (Table 2).

Similarly, the service economies of UM countries are more diversified than in LM, with the notable inclusion of financial services. Tourism, including hotels and restaurants, is a major service industry across Southeast Asia that is expanding rapidly in LM countries, with tourist arrivals growing by 148-297\% during the period of 2007-2016, while in UM countries the percentage growth rates of tourist arrivals range from $32-141 \%$ for the same time period [25]. Similar to the industrial sector, tourism is much more established in UM countries as compared to LM, considered as a major service industry in three out of the five countries of UM (Table 2). The average annual tourist arrivals for UM are over 17 million, more than four times the average of LM, which is 4 million.

Table 2. Largest industry and services areas of the countries included in this study.

\begin{tabular}{|c|c|c|}
\hline Country & Industry $^{a}$ & Services \\
\hline \multicolumn{3}{|l|}{ LM } \\
\hline Cambodia & $\begin{array}{l}\text { Garments, Construction, Rice milling, Fishing, Wood and } \\
\text { wood products, Rubber, Cement }\end{array}$ & $\begin{array}{c}\text { Trade, Transport and Communications, Real } \\
\text { Estate and Business }{ }^{\mathrm{b}}\end{array}$ \\
\hline Lao PDR & $\begin{array}{l}\text { Mining (copper, tin, gold, gypsum); Timber, Electric } \\
\text { power, Agricultural processing, Rubber, Construction }\end{array}$ & Wholesale and Retail, Tourism ${ }^{c}$ \\
\hline Myanmar & $\begin{array}{l}\text { Agricultural processing; Wood and wood products; } \\
\text { Mining (copper, tin, tungsten, iron); Cement, } \\
\text { Construction materials, Pharmaceuticals }\end{array}$ & $\begin{array}{l}\text { Wholesale and retail, information and } \\
\text { communication } \mathrm{d}\end{array}$ \\
\hline \multicolumn{3}{|l|}{ UM } \\
\hline Indonesia & $\begin{array}{l}\text { Petroleum and natural gas, Textiles, Automotive, } \\
\text { Electrical appliances, Apparel, Footwear }\end{array}$ & $\begin{array}{l}\text { Trade, hotels, and restaurants, } \\
\text { transportation and communication, } \\
\text { financial services }\end{array}$ \\
\hline Malaysia & $\begin{array}{l}\text { Rubber and oil palm processing and manufacturing, } \\
\text { Petroleum and natural gas, Light manufacturing, } \\
\text { Agriculture processing, Logging, Pharmaceuticals }\end{array}$ & $\begin{array}{l}\text { Real estate, Financial services, } \\
\text { Telecommunications }{ }^{\mathrm{f}}\end{array}$ \\
\hline Philippines & $\begin{array}{c}\text { Semiconductors and electronics assembly, Food and } \\
\text { beverage manufacturing, Construction, } \\
\text { Electric/gas/water supply, Chemical products, } \\
\text { Radio/television/communications Equipment } \\
\text { and apparatus }\end{array}$ & $\begin{array}{l}\text { Trade and repair of goods, Real estate, } \\
\text { Financial intermediation } g\end{array}$ \\
\hline Thailand & $\begin{array}{c}\text { Textiles and garments, Agricultural processing, } \\
\text { Beverages, Tobacco, Cement, Light manufacturing such } \\
\text { as jewelry and electric appliances }\end{array}$ & $\begin{array}{c}\text { Tourism, Financial Services, Wholesale } \\
\text { and Retail }^{\mathrm{h}}\end{array}$ \\
\hline Vietnam & $\begin{array}{l}\text { Food processing, Garments, Shoes, Machine-building; } \\
\text { Mining, Coal, Steel }\end{array}$ & $\begin{array}{c}\text { Tourism, Telecommunications, Wholesale } \\
\text { and Retail }\end{array}$ \\
\hline
\end{tabular}

LM's economies are forecast to be the fastest-growing in the region in the medium term of 2019-2023, with projected average annual GDP growth ranging from 6.9-7.0, while that of the other five countries in UM ranges from 3.7 to 6.6 [34]. Labor-intensive manufacturing is expected to progress in Southeast Asia in the medium term due to low labor costs, as well as the manufacturing sector in China, moving to more high-value output [35]. The continued economic growth will also mean that Southeast Asian countries will have to continually diversify their production and produce more complex goods and services [36]. Although the potential for mining expansion remains high in LM countries, it is more likely that the future focus of these countries will be on the development of their manufacturing and services sectors, which can be integrated with the supply chains of other, more developed Asian countries [37]. 


\subsection{Impact of Economic Growth on Water Security}

Overall, the current highest value industries in LM countries do not require high-quality water, but a majority are water-intensive (Table A1 in Appendix A). In LM countries, sedimentation and high biological oxygen demand (BOD) and chemical oxygen demand (COD) are the most common typical wastewater outputs based on the highest-value industries and the industries that contribute the most to water pollution, along with heavy metals, nitrogen, sulfates, and acidic water (Table A1). In $\mathrm{UM}$, the majority of top industries are also water-intensive, and more commonly require high-quality water. High BOD and COD are still top water quality concerns among UM countries, along with heavy metals. Sedimentation, nitrogen, and phosphorus are less common among the typical effluent of top industries in UM countries when compared to LM (Table A2). Pollutants that are present in contaminant-loaded surface water can also be transferred to groundwater through groundwater-surface water interaction [38]. Heavy groundwater pumping near polluted rivers can further induce the seepage of pollutants into groundwater.

Currently, surface water in LM countries is generally considered of good quality, although some deterioration has been observed in areas with urban and agricultural activity, particularly in the dry season [39]. Information on groundwater quality is limited to LM countries, although official testing by their respective national governments has found naturally occurring arsenic and other contaminants in groundwater. The quality of surface water in UM countries with available data was consistent with their income level, as $80 \%$ and $90 \%$ of rivers monitored in the upper-middle-income countries of Thailand and Malaysia received fair to good ratings for pollution, while 70\% of rivers in Indonesia are considered polluted. The most common surface water quality issue in UM countries was a high organic matter primarily attributed to domestic sources, with industrial and then agricultural sources contributing to poor water quality. For example, Malaysia reported that $99 \%$ of industries complied with effluent standards, but Biological Oxygen Demand (BOD) and nitrogen levels in surface water have risen in the past decade, pointing to an increase in household wastewater. A high amount of heavy metals was reported in groundwater monitoring wells across almost all UM countries with groundwater monitoring data, while fecal coliform, nitrates, and salinity were also reported in exceedance of national standards in multiple UM countries.

\subsection{Trends and Outlook on Urbanization}

Urbanization across Southeast Asia has been attributed to businesses moving to urban areas for proximity to both customers and their input providers, which in turn drives migrants seeking employment to these urban areas [10]. Compared to LM countries, a greater percentage of the population of $\mathrm{UM}$ is urban, and the large urban areas of $\mathrm{UM}$, in particular, have grown much faster in a span of 20 years as compared to LM (Table 3). As the contribution of services to the economies of UM countries grows, as discussed previously, the urban population is expected to increase accordingly. By 2050 , the majority of the population in UM countries is projected to be urban, with LM countries not far behind. As urbanization has increased in UM countries, income inequality, as measured by the Gini coefficient, has also increased in three out of 5 countries in UM (Table 3). Poverty is also generally lower in UM countries than in LM, although the percentage of people in poverty in Indonesia and the Philippines are similar to those in Cambodia and Laos.

The access of the population in the region to drinking water from improved sources is high, but UM countries, save for the Philippines and Indonesia, have more robust water infrastructure compared to LM countries, as seen by the access of the population to improved water sources and piped water (Table 4). Notably, access to improved and piped drinking water in the urban areas of LM is much closer to that of UM as compared to the rural areas of LM, which still lag noticeably behind the rural areas of UM. The gap between urban and rural drinking water in the same countries is also larger in LM countries than those in UM. 
Table 3. Regional trends on urbanization and inequality from 2000 to 2018 [25,35].

\begin{tabular}{|c|c|c|c|c|c|c|c|c|c|c|}
\hline & \multicolumn{4}{|c|}{ Urban Pop (\% of Total Pop) } & \multicolumn{2}{|c|}{ Pop. in Urban Areas >1 M (\% Total Pop.) } & \multicolumn{2}{|c|}{ Pop. Below Natl Poverty Line (\%) } & \multicolumn{2}{|c|}{ Gini Coefficient } \\
\hline & 2000 & 2018 & 2030 & 2050 & 2000 & 2018 & 2007 & 2016 & 2007 & 2016 \\
\hline \multicolumn{11}{|l|}{ LM } \\
\hline CAM & 18.59 & 23.39 & 29.00 & 41.20 & 9.45 & 12.01 & 30.10 & 14.00 & 0.44 & 0.31 \\
\hline $\mathrm{LAO}$ & 21.98 & 35.00 & 42.90 & 55.70 & N/A & N/A & $27.6^{\mathrm{b}}$ & 23.20 & $0.37^{\mathrm{b}}$ & $0.38^{\mathrm{a}}$ \\
\hline MYA & 27.03 & 30.58 & 35.00 & 47.10 & 14.24 & 14.28 & $25.6^{c}$ & 32.10 & $\mathrm{~N} / \mathrm{A}$ & N/A \\
\hline \multicolumn{11}{|l|}{ UM } \\
\hline IND & 42.00 & 55.33 & 62.80 & 72.80 & 12.09 & 13.38 & 16.60 & 10.90 & 0.36 & 0.40 \\
\hline MAL & 61.98 & 76.04 & 81.80 & 87.30 & 18.01 & 23.99 & 3.60 & 0.40 & 0.44 & 0.40 \\
\hline PHI & 46.14 & 46.91 & 50.90 & 61.80 & 9.46 & 12.16 & 26.30 & 21.60 & $0.46^{\mathrm{d}}$ & $0.4^{\mathrm{a}}$ \\
\hline THA & 31.39 & 49.95 & 58.40 & 69.50 & 12.76 & 20.06 & 20.90 & 8.60 & 0.40 & $0.45^{a}$ \\
\hline VIE & 24.37 & 35.92 & 44.50 & 57.30 & 9.58 & 16.91 & 14.80 & 7.00 & $0.43^{b}$ & 0.44 \\
\hline
\end{tabular}

Table 4. Regional trends in sanitation and water supply from around 2000 to present [39] (All figures refer to population percentages).

\begin{tabular}{|c|c|c|c|c|c|c|c|c|c|c|c|c|c|}
\hline & \multirow{2}{*}{ Year } & \multicolumn{4}{|c|}{ Urban } & \multicolumn{4}{|c|}{ Rural } & \multicolumn{4}{|c|}{ National } \\
\hline & & $\begin{array}{l}\text { Improved } \\
{ }_{1} \text { Sani. }\end{array}$ & Sewer & $\begin{array}{c}\text { Improved } \\
{ }^{2} \mathrm{H}_{2} \mathrm{O}\end{array}$ & $\begin{array}{c}\text { Piped } \\
\mathrm{H}_{2} \mathrm{O}\end{array}$ & $\begin{array}{c}\text { Improved } \\
\text { Sani. }\end{array}$ & Sewer & $\begin{array}{c}\text { Improved } \\
\mathrm{H}_{2} \mathrm{O}\end{array}$ & $\begin{array}{c}\text { Piped } \\
\mathrm{H}_{2} \mathrm{O}\end{array}$ & $\begin{array}{l}\text { Improved } \\
\text { Sani. }\end{array}$ & Sewer & $\begin{array}{c}\text { Improved } \\
\mathrm{H}_{2} \mathrm{O}\end{array}$ & $\begin{array}{c}\text { Piped } \\
\mathrm{H}_{2} \mathrm{O}\end{array}$ \\
\hline \multicolumn{14}{|l|}{ LM } \\
\hline \multirow{2}{*}{ CAM } & 1999 & 32.8 & 2.5 & 66.5 & 8.8 & 10.2 & 0.2 & 48.6 & 1.8 & 16.7 & 3.8 & 54.3 & 6.4 \\
\hline & 2016 & 94.2 & 51.5 & 94.6 & 77.8 & 69.0 & 3.4 & 72.6 & 17.2 & 74.2 & 13.4 & 77.2 & 29.8 \\
\hline \multirow{2}{*}{ LAO } & 2000 & 58.8 & 1.0 & 83.3 & 37.4 & 12.3 & 0.0 & 38.0 & 6.7 & 22.5 & 0.2 & 48.0 & 13.5 \\
\hline & 2017 & 94.1 & 1.3 & 95.5 & 88.8 & 65.0 & 0.9 & 72.7 & 42.9 & 73.9 * & $1.0^{*}$ & $79.6^{*}$ & $56.9^{*}$ \\
\hline \multirow{2}{*}{ MYA } & 2001 & 94.9 & 10.6 & 77.9 & 22.8 & 77.5 & 0.6 & 58.0 & 5.8 & $82.2 *$ & $3.3^{*}$ & 64.0 & 10.1 \\
\hline & 2016 & 76.9 & 0.8 & 93.3 & 59.1 & 51.1 & 0.1 & 78.6 & 12.7 & 58.0 & 0.3 & 82.5 & 25.2 \\
\hline \multirow{3}{*}{ IND } & & & & & & & & & & & & & \\
\hline & 2001 & 67.7 & - & 90.5 & 33.6 & 30.1 & - & 67.0 & 6.5 & 46.3 & - & 77.2 & 18.3 \\
\hline & 2018 & 90.3 (2016) & 9.5 & 95.6 & 13.2 & 76.7 & 13.5 & 82.5 & 6.8 & 83.4 & 11.6 & 82.9 & 10.3 \\
\hline \multirow{2}{*}{ MAL } & 2003 & 98.9 & 42.2 & 99.8 & 96.4 & 97.1 & 11.9 & 98.7 & 88.0 & $98.3^{*}$ & $31.5^{*}$ & 99.4 * & 93.4 * \\
\hline & 2016 & - & - & 99.6 & 99.1 & - & - & 92.3 & 84.5 & 100.0 & 77.0 & 95.9 & 95.9 \\
\hline \multirow{2}{*}{ PHI } & 2000 & 92.7 & 7.3 & 89.8 & 62.1 & 71.6 & 1.8 & 76.9 & 31.8 & $82.0 *$ & $4.3 *$ & $82.9 *$ & 45.8 * \\
\hline & 2017 & 93.7 & 7.0 & 98.4 & 31.3 & 84.2 & 2.4 & 94.4 & 28.0 & 88.8 & 4.6 & 96.2 & 29.5 \\
\hline \multirow[b]{2}{*}{ THA } & 2000 & 100.0 & - & 99.8 & 89.7 & 98.6 & - & 92.4 & 18.1 & 98.8 & - & 94.2 & 35.5 \\
\hline & 2016 & 99.6 & 10.8 & 99.7 & 85.8 & 99.6 & 5.2 & 98.1 & 53.3 & 99.6 & 7.8 & 99.0 & 68.7 \\
\hline \multirow{2}{*}{ VIE } & 2000 & 86.2 & 2.9 & 96.7 & 50.6 & 51.4 & 0.2 & 73.5 & 0.8 & 22.5 & 0.9 * & 79.0 & 12.6 \\
\hline & 2016 & 96.9 & 1.4 & 98.2 & 77.4 & 81.7 & 0.5 & 87.1 & 21.4 & 86.8 & 0.8 & 90.7 & 39.3 \\
\hline
\end{tabular}

* National figures estimated using population data. ${ }^{1}$ Improved sanitation refers to "sanitation facilities that hygienically separate human excreta from human contact" and can range from pit latrines with a slab to those with sewer connections. ${ }^{2}$ Improved drinking water sources are "those that have the potential to deliver safe water by nature of their design and construction, and include: piped water, boreholes or tube wells, protected dug wells, protected springs, rainwater, and packaged or delivered water.". 
Similar to the trend in water access, a greater part of the population of UM countries have access to improved sanitation sources as compared to LM countries (Table 4). In Cambodia and UM countries, except for Malaysia, septic tanks are the most common type of improved sanitation facility, with around $59-89 \%$ of the population able to access these [39]. For Myanmar and Laos, improved latrine systems are the most common, with 64.8 and $57.2 \%$ of their population respectively being able to access these. Sewer infrastructure is present only among a minority of the population, even in most UM countries, with the percentage of the population in UM countries with sewer connections being comparable to LM counterparts save for Malaysia.

\subsection{Impact of Urbanization on Water Security}

Domestic water for drinking in urban areas is most commonly sourced from surface water in Laos, Myanmar, and Malaysia [38]. In contrast, the majority of water users in Cambodia and UM countries aside from Malaysia depend on groundwater as their primary drinking water source, ranging from around $20 \%$ in urban and $50 \%$ in rural areas in Cambodia to at least $90 \%$ in both urban and rural areas in Indonesia [40]. Across the region, groundwater usage is prevalent among domestic users in rural areas. In LM countries, groundwater usage is rising due to demand from an increasing population, as well as seasonal demand during the summers [38]. The increased use of electrified water pumps for domestic use could also increase groundwater extraction rates [40]. The main quality issue for domestic groundwater is contamination from wastewater and leakage of on-site sanitation facilities. Other important quality issues are contamination from pesticides, industrial sources, and saline intrusion [40]. Some of the population have responded to these issues by tapping deeper levels of groundwater. Surface water pollution in the region has also been found to impact the groundwater quality significantly [41].

Less than 15\% of the population in UM countries (aside from Malaysia) and Cambodia are connected to a sewerage system. Even the affluent capital cities of UM countries are not completely covered by sewerage treatment systems, as for example, only $30 \%$ of sewage is treated in Hanoi and $50 \%$ in Bangkok [42]. Sewage treatment facilities are typically built at a national per capita GDP of $\$ 5000$, which has not been yet reached by countries in the region other than Thailand and Malaysia but are now being planned and built in some cities in the regions which have a per capita GDP approaching $\$ 5000$ [42]. Septic tanks, which are the predominant form of sanitation facility in most UM countries and Cambodia, generally require the initiative of private owners to empty, and according to surveys in Indonesia and Vietnam, 66 and 75\% have never done so [43]. Substandard septic tanks and sanitation facilities lower than the level of septic tanks, such as improved pit latrines, can leach contaminants such as nitrogen, phosphorus, and disease-causing microbes into groundwater [44]. Pollution from household sanitation facilities can even affect the quality of water from wells used by the same household depending on proximity.

\subsection{Trends and Outlook on Climate Change}

Precipitation in Southeast Asia is dominated by the presence and absence of monsoons, with most countries in the region experiencing a distinct wet monsoon period during the boreal summer months of June-October and a dry period during the months of December-April, with May and November as transition months $[45,46]$. Throughout the 20th and early 21st-century, precipitation trends in Southeast Asia have indicated an increase in intensity for both dry and wet periods, both low and high precipitation events increased in frequency [47]. Extreme wet and dry conditions during the wet monsoon period have also both increased [47].

The boreal summer months, which see the strongest monsoon activity, also correspond to the months where tropical cyclones are most active. Out of the Southeast Asian countries, the Philippines and Vietnam are most affected by cyclones due to these countries' geographical locations [33], directly facing the Pacific Ocean and the South China Sea, respectively. Vietnam receives up to $25 \%$ of its precipitation from cyclones during the wet season [48], while the Philippines can receive up to 53\% [49]. 
The high frequency of cyclone events in the Philippines and Vietnam affects many people and is estimated to cause the highest total damage out of different hydrometeorological disasters that affect both countries (Table 5). For the Philippines, in particular, cyclones are, without a doubt, the most impactful disaster, as they have the highest value in all four impact criteria considered over the period of 1998-2018. The high damage potential of cyclones is underscored by Laos and Myanmar, where although less than 10 cyclone disaster events were experienced in these two countries during the last twenty years, cyclones still affected the most people and caused the most damage both per event and in total. Counted among the cyclone events in Myanmar is Cyclone Nargis, which is the worst natural disaster in Myanmar's history, and the eighth deadliest cyclone worldwide as of 2009 [50]. 
Table 5. Impact of hydro-meteorological disasters in LM and two countries during 1998-2018. Values in bold indicate the highest value of each impact criteria per country. Data compiled by the authors from UCL et al. [51].

\begin{tabular}{|c|c|c|c|c|c|c|c|c|c|c|c|c|}
\hline & \multicolumn{4}{|c|}{ Drought } & \multicolumn{4}{|c|}{ Flood } & \multicolumn{4}{|c|}{ Cyclone } \\
\hline & Freq. & $\begin{array}{l}\text { Avg. Pop } \\
\text { Affected }\end{array}$ & $\begin{array}{l}\text { Avg. Total Dmg. } \\
\text { (‘000 US\$) }\end{array}$ & $\begin{array}{l}\text { Est. Total Dmg. } \\
\text { ('000 US\$) }\end{array}$ & Freq. & $\begin{array}{l}\text { Avg. Pop } \\
\text { Affected }\end{array}$ & $\begin{array}{l}\text { Avg. Total Dmg. } \\
\text { (‘000 US\$) }\end{array}$ & $\begin{array}{l}\text { Est. Total Dmg. } \\
\text { ('000 US\$) }\end{array}$ & Freq. & $\begin{array}{l}\text { Avg. Pop } \\
\text { Affected }\end{array}$ & $\begin{array}{l}\text { Avg. Total Dmg. } \\
\text { (‘000 US\$) }\end{array}$ & $\begin{array}{l}\text { Est. Total Dmg } \\
\text { (‘000 US\$) }\end{array}$ \\
\hline \multicolumn{13}{|l|}{ LM } \\
\hline CAM & 4 & $1,012,500$ & $38,000.00$ & $152,000.00$ & 17 & 922,867 & $141,066.67$ & $2,398,133.39$ & 4 & 92,196 & N/A & N/A \\
\hline MYA & 1 & N/A & N/A & & 22 & 251,341 & $40,900.00$ & $899,800.00$ & 8 & 589,526 & $1,015,572.00$ & $8,124,576$ \\
\hline \multicolumn{13}{|l|}{ UM } \\
\hline IND & 2 & 7506 & 1000.00 & 2000.00 & 126 & 265,702 & $460,817.92$ & $58,063,057.92$ & 5 & 5433 & 1000.00 & 5000 \\
\hline MAL & 2 & $1,102,500$ & N/A & & 38 & 45,377 & $202,714.29$ & $7,703,143.02$ & 5 & 10,520 & N/A & N/A \\
\hline PHI & 4 & $1,390,843$ & 453.00 & 1812.00 & 98 & $1,217,388$ & $164,329.29$ & $16,104,270.42$ & 167 & $5,856,915$ & $864,239.19$ & $144,327,944.73$ \\
\hline VIE & 4 & $1,215,000$ & $2,330,706.67$ & $9,322,826.68$ & 69 & $1,175,183$ & $199,401.95$ & $13,758,734.55$ & 63 & 965,614 & $490,492.89$ & $30,901,052.07$ \\
\hline
\end{tabular}


In contrast, floods have the most significant impact in all other countries in the region, as seen in Table 5. Over a span of the last twenty years, flood disaster events have been the most frequent disaster event in UM countries aside from the Philippines and Vietnam, as well as in Cambodia. In these countries and particularly in Thailand, floods have caused the most economic damage as compared to the cyclone disaster events that they experienced. Indonesia is also particularly affected by floods, as it has experienced the highest number of flood disaster events, with each event causing the second-highest amount of damage across the region. Flood disasters are much more frequent in UM countries rather than in LM countries, but floods are still the most frequently occurring disaster in the latter group.

Across the region, drought disaster events occur less often than floods or cyclones. Although there is a lack of data regarding the monetary damage caused by drought events, Vietnam, Cambodia, and Thailand are particularly affected by droughts in terms of either population affected or damage caused. Overall, the economic cost of natural disasters is substantial, ranging from 1 to almost $1 \%$ of GDP lost annually across both groups of countries [34]. Out of the UM countries, those currently most affected by natural disasters according to this metric are Vietnam, Thailand, and the Philippines, with $1-6 \%$ of GDP lost annually [34]. Out of the LM countries, Cambodia is an outlier, losing almost 7\% of its GDP annually to disasters, while Myanmar and Lao PDR lose less than 2\% [34]. On the whole, UM countries are currently more vulnerable than LM countries to disasters that could be intensified with climate change, especially in terms of exposure, but Laos and Cambodia in LM are still highly vulnerable to climate change due to their low adaptive capacity [52].

Models indicate that the trend of more intense precipitation events during the wet season coupled with less intense precipitation during the dry season (as described in the previous section) will continue in the future for most of Southeast Asia [53]. There is significant spatial variation across the region, as precipitation changes are expected to be negligible in both dry and wet seasons in the LM countries and Thailand. Similarly, precipitation extremes related to the monsoon in Southeast Asia are also expected to be more intense [54]. However, models are inconclusive regarding future increases or decreases in the total amount of rain that the monsoon brings. Although it is likely that the frequency of cyclones will remain the same or decrease slightly, the Intergovernmental Panel on Climate Change (IPCC) has projected that the rainfall associated with the center of cyclones, as well as the wind in cyclones, will intensify [54]. Some researchers have then attributed the predicted overall increase in intense precipitation events during wet seasons across the region to stronger cyclones, particularly in coastal Vietnam [53].

Other countries in Southeast Asia will be most affected by increased flooding [55] and streamflow seasonality. Although the mean annual streamflow across the region is not expected to change, models predict that streamflow will decrease during low flow periods and increase during high flow periods [56]. Thus, countries will be more at risk of droughts during dry seasons and floods during wet seasons. Taking the projected streamflow and changes in the precipitation together, the total water quantity in Southeast Asia is not expected to change drastically due to climate change, but the whole region will experience increased variability in the wet and dry seasons.

\subsection{Impact of Climate Change on Water Security}

Climate change is projected to affect water quality in Southeast Asia through an increase in water temperatures, a decrease in streamflow during low-flow periods, and an increase in risk from salinization due to storm surges and sea-level rise. The temperatures of inland water bodies in the region are expected to increase by 5 to $2.0 \mathrm{C}$ by the end of this century [56]. Increasing water temperatures will result in more ideal conditions for the growth of algae and bacteria, decreasing the quality of water for all uses [57]. A decrease in streamflow during low flow periods will also decrease the dilution of pollutants, resulting in increased effluent loads, including heavy metals and agricultural byproducts. The intensification of disasters due to climate change is will likely aggravate the existing salinization of groundwater in coastal areas in the area through stronger storm surges 
caused by stronger cyclones [58]. A long-term effect of climate change on water quality in coastal areas is sea-level rise, which would again increase the salinity of groundwater reserves in coastal areas [54]. With worsening water quality due to an increase in water temperatures and a decrease in streamflow, users in all sectors will thus have to invest additional resources in water treatment for portability and to ensure that the temperature is suitable for commercial and industrial processes.

More pronounced seasonality of precipitation and streamflow across the region will result in water stress in terms of quantity during the dry season. A decrease of access to aboveground water sources will drive more users to tap groundwater, which has already been extracted extensively in major cities in Southeast Asia [59]. There would be increased demand for groundwater, especially during the dry summer season, and would particularly increase across currently developing cities. Access to water could also be affected due to damage to water infrastructure, first during the more intense wet season due to increased damage to water transportation networks because of stronger cyclones and increased flood risk [60]. Second, the damage sustained by water supply and storage networks during the more intense wet season could also limit water access during the dry season due to the need for repair and rehabilitation.

\section{Discussion}

\subsection{UM: Focus on the Impact of Disasters on Water Security in Urban Areas}

\subsubsection{Immediate Impacts of Disasters on Water Security}

A key point of focus of future water security in UM countries will be the impact of disasters on water resources, an area that not has been properly considered in disaster planning [61]. Going forward, the effect of flooding on water quality will have an increasingly greater impact on the water security of UM cities. Floods, the most common disaster event across UM, can carry pollutants, including agricultural and industrial chemicals, directly into both water sources and groundwater access points such as wells [62]. In urban areas, floods can damage sanitation infrastructure, which can cause the overflow of raw sewage, and therefore, further contamination of drinking water [63]. Septic tanks, the use of which is prevalent among UM countries, do not seem to be a major contributor to groundwater contamination during normal flood events [64], but overflow has been observed during strong floods [65]. Existing industrial areas in UM that are located near urban areas could be possible sources of chemical contaminants as floods occur, and floodwaters wash through industrial areas and carry contaminants to rivers and into groundwater supplies. However, surface water quality in this context is only temporarily decreased by floods, as the quality of rivers contaminated by floodwater that has washed over pollutant-heavy floodplains returns to normal after around 30-40 h [66]. In growing UM cities that will experience more intense floods, disaster planning for the aftermath of floods should consider the immediate reduction of water quality, particularly as a result of damage to sanitation infrastructure.

\subsubsection{Long-Term Impacts of Disasters on Water Security and Development}

The combination of environmental and economic change will modify the context in which UM countries will address external shocks and stressors. As UM countries continue to transition towards a service-oriented economy, more people in rural areas will be drawn towards major cities, many of which are located in coastal areas. In these growing major cities, higher-intensity floods can decrease water quality for a longer period of time by damaging water treatment or access infrastructure. Prolonged flood events can also delay the start of infrastructure rehabilitation and repair. High-velocity flash floods can damage every part of the water supply systems, such as intakes, reservoirs, pumping equipment, and electrical installations [63]. With more intense floods, there is a larger chance of a long-term decrease in water quality through infrastructure damage. As a result, the expansion of piped water access in the cities of UM could be delayed, which will be more crucial as urbanization 
grows to respond to the rise of services. The slow expansion could particularly be seen in fringe areas where population growth is faster than in the urban center [67]. Out of all UM countries, the Philippines and Indonesia could be the most affected by delayed expansion, as the majority of the urban population in these two countries does not have access to piped water.

Floodwater and stormwater management should be important areas of focus for UM areas, particularly in urban areas, in order to avert the effects of disasters on water quality. Aside from the management of the actual floodwaters, the protection of drinking water access points and infrastructure from floods should be important parts of long-term urban water planning. For the private sector, financing climate change adaptation measures is considered a hurdle that is more likely to overcome if they can offset the costs to consumers or they receive subsidies for the costs of adaptation [68]. If the industrial sector is not able to prepare for more intense floods and does sustain repeated damage to their water storage and access infrastructure, economic development in that sector could be slowed as a high quality and quantity of water is needed to sustain many UM industries. Disruption in the production of goods could also affect the retail service sector, which relies on a regular schedule of production throughout the supply chain [68].

\subsection{UM: Additional Effect of Cyclones on the Philippines and Vietnam}

Out of the UM countries, the Philippines and Vietnam will be the least water-secure as they are vulnerable to both frequent floods and cyclones, both of which are projected to increase in intensity. Destructive cyclones can lower water quality for a longer time as strong winds and torrential rain add to the damage potential of floods explained in the previous paragraph. For example, excessive coliform was still observed in groundwater months after an extremely strong typhoon hit the Philippines, and its presence was attributed mainly to the destruction of sanitation facilities [69]. Strong winds can damage both aboveground buildings housing water supply equipment and belowground infrastructure, such as water pipes through tree uprooting. Storm surges from cyclones have been shown to result in the salinization of both surface water and coastal aquifers, and in some cases, models predict that it might take years before infiltrating rainfall flushes infiltrated saltwater to surrounding water bodies [70,71]. Major metropolitan areas in the Philippines and Vietnam that are located on coastlines already experience salinization due to massive groundwater pumping [72,73]. With the increasing intensity of cyclones coupled with increasing migration to large coastal cities due to perceived employment opportunities in the services sector, the Philippines and Vietnam will have to deal with increased salinization from storm surges and an increased chance of human waste contamination due to sanitation infrastructure damage. This is in addition to the dynamic of decreasing water quality as a result of more intense floods present in all UM countries.

\subsection{UM: Water Quantity Most Important during Dry Seasons}

During dry seasons, water quantity issues will be paramount over water quality concerns for the UM. As the majority of the countries in the UM mostly depend on groundwater [38], water users should not be overly affected by drops in water quality due to streamflow decreases during the dry season. Quantity issues, on the other hand, will surface in the dry seasons due to decreased precipitation and increasing domestic water demand. Surface water users in this group will be beset by water quantity issues in the dry season and water quality during the wet season. Floodwater and stormwater projects, aside from protecting current water resources, should also promote water treatment, reuse, and storage in preparation for the dry seasons.

\subsection{LM: Overall Less Water Secure than UM, Water Quality More Important than Quantity in the Short-Term}

Water security in LM will be lowest during dry seasons due to water quality and quantity pressure from the combination of climate change, economic development, and urbanization, coupled with high usage of surface water. Many extractive industries are still among the highest-value industries in LM, and industry effluent regulations are not yet as stringent in these countries as in UM countries. Surface 
water is utilized by around $90 \%$ of water users in Laos and Myanmar, as well as by the industry in Cambodia [38]. Thus, these users will be increasingly susceptible to the negative effects of industrial effluent as the industry becomes a bigger part of these countries' economies. In addition to a decrease in water quality due to an increasing industry effluent, climate change will also reduce water quality during the dry season through decreasing streamflow and higher water temperatures. Groundwater usage is projected to rise in LM due to a growing demand from the domestic and industrial sector, and especially during the dry season [38]. In addition to growing demand, decreasing water supply during dry seasons could further encourage the usage of groundwater. Increasing groundwater usage could introduce additional quality issues. First, pumping groundwater near polluted rivers could induce seepage of contaminants into groundwater. For example, massive groundwater pumping near Hanoi has increased the level of arsenic in the aquifer through drawing in river water, which has arsenic-loaded sediment [74]. Second, household groundwater wells could be contaminated by leakage of effluent from pit latrines and septic tanks, which are the most common forms of sanitation in LM, depending on proximity. Although the water in LM is considered abundant at present [38], LM water withdrawals are expected to increase in the future due to rising household income and industrial expansion. As agriculture is still a major part of the economy of LM countries, water use may drop in the near-term as their economies start to transition towards services and industry. However, in the long term, it is predicted that water quantity stress will be felt primarily due to industrial and domestic water use rather than irrigation [75]. In the short-term, water quality rather than quantity issues could be more pressing for LM countries to address, as quantity shortages during the dry season can be filled through increasing groundwater usage.

Even though LM has less exposure to disaster events than UM, LM can still be affected by infrequent, high-damage disaster events, particularly cyclones in the case of Laos and Myanmar. As discussed in the previous section, cyclones can damage water infrastructure, and so have the potential to affect water security both immediately and for longer durations of time depending on the speed of repair of the infrastructure. Water infrastructure should, therefore, be constructed to withstand great damage, and urban water planning should include the effects of these disasters, as they are projected to intensify. In this case, damage to water infrastructure is sustained during these events, rehabilitation and repair could take longer in LM compared to UM countries due to their lower adaptive capacity.

As quality is the most important issue for LM, sanitation programs and regulation of industrial effluent should be emphasized in the near term, as well as continuing to improve water access and quality. High-quality water is required for the diversification of economies if LM is to follow the footsteps of UM, and similarly, UM industries are still water-intensive. Not addressing quality and quantity issues, especially during the dry season and not disaster-proofing water supply and sanitation infrastructure, could, therefore, slow LM's transition to the more diverse economies and bigger urban areas of the UM countries.

\section{Conclusions}

Southeast Asia is one of the world's most economically dynamic regions, as well as, one of the regions that are most vulnerable to the effects of climate change. The fast-growing cities in Southeast Asia have to simultaneously address different levels of water challenges, such as increasing access to drinking water and sanitation and planning for increased flooding, at lower income levels as compared to the experience of cities in the global North [59]. This paper uses the double exposure framework to reveal unequal water security outcomes as a result of multiple pressures, as well as changes in context as a result of these pressures. The region-wide scope of this paper adds to previous work on double exposures in urban Southeast Asia conducted at smaller scales [16-18]. In this paper, water quality emerges as the most important future water security concern for the whole region. Specifically, (1) more intense disasters, especially flooding, have the potential to decrease water quality in the UM countries of Indonesia, the Philippines, Vietnam, Malaysia, and Thailand immediately after the event, as well as for a longer period of time through infrastructure damage; (2) in UM, the Philippines and Vietnam 
will have the lowest future water security as they are both more vulnerable to cyclones, which have higher damage potential for water supply and sanitation infrastructure damage compared to other UM countries; and (3) in the LM countries of Cambodia, Myanmar, and Lao PDR, water quality will be the more important water security challenge in the short-term as opposed to water quantity due to large growth in industry and high surface water usage. Although less exposed to disaster events than UM, LM will still have lower future water security compared to UM as they have to build capacity to address water quantity and quality challenges, particularly in the dry season. Having to address these challenges may result in a long time of transition for LM countries to the more diversified economies and better water and sanitation access of UM. The importance of water quality in ensuring water security across Southeast Asia suggests that it should be a focus of future water-related development projects conducted in the region at all levels. The results of this review further suggest that building the robustness of water infrastructure to disaster events and planning for sanitation to cover expanding urban areas will be crucial to ensure future water security in terms of water quality across the region. These two actions will be salient for the sustainable development of both the region's emerging cities and its established mega metropolitan areas.

Author Contributions: Conceptualization-T.E.L. and A.P.K.; investigation-T.E.L.; writing—original draft preparation-T.E.L.; writing-review and editing-A.P.K. All authors have read and agreed to the published version of the manuscript.

Funding: This research received no external funding.

Conflicts of Interest: The authors declare no conflict of interest.

\section{Appendix A}

Table A1. Water quality and quantity input and output by industry type.

\begin{tabular}{|c|c|c|c|}
\hline Industry & Quality of $\mathrm{H}_{2} \mathrm{O}$ Input & $\mathrm{H}_{2} \mathrm{O}$ Output Pollutants & $\begin{array}{l}\text { Country where Industry } \\
\text { Is Prominent }[25,38]\end{array}$ \\
\hline Agricultural Processing [76] & $\begin{array}{l}\text { Assumed to be similar to rice milling: high amount } \\
\text { of potable but not high-quality water needed }\end{array}$ & $\begin{array}{l}\text { High organic pollutants, contributes to high } \\
\text { TS, Nitrogen, TP, BOD and COD, and } \\
\text { pathogens }\end{array}$ & LAO, MYA, MAL, THA \\
\hline Cement $[77,78]$ & $\begin{array}{l}\text { Not potable, used for cooling, mostly recycled within } \\
\text { a factory }\end{array}$ & "No substantial contribution", possibly TDS & CAM, MYA, THA \\
\hline Chemical Products [79] & $\begin{array}{l}\text { Mostly used for cooling ( } 90 \% \text { of water intake) and in } \\
\text { processes. Since water mostly used for cooling, } \\
\text { assumed that high-quality water not required }\end{array}$ & $\begin{array}{l}\text { Oil and grease, High BOD and COD, heavy } \\
\text { metals }\end{array}$ & PHI \\
\hline Construction [80-83] & $\begin{array}{l}\text { Quantity required "minimal" compared to the } \\
\text { quantity of water needed for the generation of } \\
\text { materials. Removal of vegetation, grading activities, } \\
\text { cleaning, concrete mixing and casting, washing, } \\
\text { drilling, cleaning, etc., potable water can be used but } \\
\text { is not required }\end{array}$ & $\begin{array}{l}\text { Mainly sedimentation, on a lesser scale } \\
\text { chemicals, nutrients, oil and grease, metals }\end{array}$ & CAM, LAO, MYA, PHI \\
\hline $\begin{array}{l}\text { Electric/Gas/Water supply } \\
\text { [84-87] }\end{array}$ & $\begin{array}{l}\text { Coal: a large amount of water needed for cooling, } \\
\text { but quality is not important }\end{array}$ & $\begin{array}{c}\text { Hydropower: sedimentation, water } \\
\text { released may have low DO, either higher or } \\
\text { lower water temp } \\
\text { Coal (majority of PHI): groundwater } \\
\text { contamination: arsenic, Hg, heavy metals: } \\
\text { Cd, Cobalt, Selenium }\end{array}$ & LAO (hydropower) PHI \\
\hline $\begin{array}{l}\text { Electronics/Semiconductors } \\
\text { Assembly }[88,89]\end{array}$ & Large quantity of ultrapure water needed & $\begin{array}{l}\text { Cl, sulfates, FL, Nitrates, Phosphates, } \\
\text { Heavy metals, some organics, cyanide, } \\
\text { contributes to high COD }\end{array}$ & PHI \\
\hline $\begin{array}{l}\text { Electric Appliances/Machine } \\
\text { Building [90-92] }\end{array}$ & $\begin{array}{l}\text { Machinery water use not very high compared to } \\
\text { other sectors, electric appliances even more less so. It } \\
\text { is assumed that potable water is not required. }\end{array}$ & $\begin{array}{l}\text { Heavy metals, generally low water } \\
\text { pollution compared to other manufacturing } \\
\text { industries }\end{array}$ & PHI, THA, VIE, IND \\
\hline $\begin{array}{l}\text { Food and Beverage Processing } \\
\qquad \text { [93-95] }\end{array}$ & $\begin{array}{l}\text { High water quality and high quantity needed: } \\
\text { further treatment usually required }\end{array}$ & $\begin{array}{l}\text { Strong organic content, contributing to high } \\
\text { BOD, TSS }\end{array}$ & VIE, IND, PHI, THA, \\
\hline $\begin{array}{l}\text { Logging, wood and wood } \\
\text { Processing [96-98] }\end{array}$ & $\begin{array}{l}\text { Cooling saw blades, wood preserving, storm runoff, } \\
\text { dusting (from these uses, it is assumed that potable, } \\
\text { high-quality water is not needed) }\end{array}$ & $\begin{array}{l}\text { Nitrogen, Phosphorus, organic waste } \\
\text { compounds, wood preservation chemicals } \\
\text { (chrome, copper, arsenic) contributing to } \\
\text { high BOD and COD, increased water } \\
\text { turbidity (TSS), oil and grease Note: } \\
\text { pollution mostly happens in storm runoff }\end{array}$ & CAM, LAO, MAL, MYA \\
\hline
\end{tabular}


Table A1. Cont.

\begin{tabular}{|c|c|c|c|}
\hline Industry & Quality of $\mathrm{H}_{2} \mathrm{O}$ Input & $\mathrm{H}_{2} \mathrm{O}$ Output Pollutants & $\begin{array}{l}\text { Country where Industry } \\
\text { Is Prominent }[25,38]\end{array}$ \\
\hline Petrochemical [108-111] & $\begin{array}{l}\text { Water intensive, used for distillation, liquid } \\
\text { extraction, washing, and cooling, can use water } \\
\text { directly from freshwater sources }\end{array}$ & $\begin{array}{c}\text { SS, organic compounds (hydrocarbons), } \\
\text { phenols, grease, } \mathrm{H}_{2} \mathrm{~S}, \mathrm{NH}_{3}, \mathrm{CN}^{-} \\
\text {contributes to high BOD and } \\
\text { COD, hardness }\end{array}$ & IND, MAL \\
\hline Rice Milling [77] & $\begin{array}{l}\text { Large amount of water input needed (parboiling, } \\
\text { washing, steaming). From these uses, it is assumed } \\
\text { that potable but not high-quality water is needed }\end{array}$ & BOD, COD, TSS, nitrogen (nitrates, TKN) & CAM \\
\hline Textiles/Apparel [116-118] & Large amount of water input needed & $\begin{array}{l}\text { Untreated dye, heavy metals (ex. } \mathrm{Pb}, \mathrm{Hg}, \\
\mathrm{Zn} \text { ), organic pollution, sulfates, contributes } \\
\text { to high BOD, COD, some TDS }\end{array}$ & CAM, IND, THA, VIE \\
\hline Steel $[100,119]$ & $\begin{array}{l}\text { Water input-intensive, used in furnaces, cooling, } \\
\text { washing, and product isolation. From these uses, } \\
\text { assumed that high-quality water is not needed. }\end{array}$ & $\begin{array}{l}\text { Oil and grease, high BOD and COD, } \\
\mathrm{NH}_{3}-\mathrm{N} \text {, organic compounds, TDS, heavy } \\
\text { metals, cyanide, acids, }\end{array}$ & VIE \\
\hline Vehicles [120-123] & $\begin{array}{l}\text { Used for washing and coloring, use freshwater that } \\
\text { is further processed in the plant itself }\end{array}$ & $\begin{array}{l}\text { High BOD, COD, heavy metals, oil and } \\
\text { grease, organic and inorganic } \\
\text { pollutants (phosphate) }\end{array}$ & IND \\
\hline
\end{tabular}

Table A2. Summary of water quality and quantity requirements and output by highest value and most polluting industries per country using data from Table A1.

\begin{tabular}{|c|c|c|}
\hline Country & Water Quality & Water Quantity \\
\hline \multicolumn{3}{|l|}{$\mathbf{L M}$} \\
\hline CAM & $\begin{array}{l}\text { Input: High-quality water is not needed for any main industry; potable or } \\
\text { non-potable water can be used. } \\
\text { Output: Sedimentation is most common quality output concern, along with } \\
\text { high organic pollution (BOD and COD). Lesser scale: nitrogen, sulfates, } \\
\text { heavy metals. }\end{array}$ & $\begin{array}{l}\text { High amount of water needed in } \\
3 / 5 \text { top industries. }\end{array}$ \\
\hline $\mathrm{LAO}$ & $\begin{array}{l}\text { Input: High-quality water is not needed for any main industry; potable or } \\
\text { non-potable water can be used with some processing. } \\
\text { Output: Sedimentation is the most common quality output concern, along } \\
\text { with high organic pollution (BOD and COD). Lesser scale: nitrogen, sulfates, } \\
\text { phosphates, heavy metals, acidic water, oil and grease. }\end{array}$ & $\begin{array}{l}\text { High amount of water needed in } \\
3 / 5 \text { top industries. }\end{array}$ \\
\hline MYA & $\begin{array}{l}\text { Input: High-quality water only needed for pharmaceutical industries, for } \\
\text { others potable or non-potable water can be used with some processing. } \\
\text { Output: Sedimentation is most common quality output concern, along with } \\
\text { high organic pollution (BOD and COD) and nitrogen. Lesser scale: sulfates, } \\
\text { phosphates, heavy metals, acidic water, oil and grease. }\end{array}$ & $\begin{array}{l}\text { High amount of water needed in } \\
2 / 5 \text { top industries. }\end{array}$ \\
\hline \multicolumn{3}{|l|}{ UM } \\
\hline IND & $\begin{array}{c}\text { Input: High-quality water needed for only } 1 / 5 \text { industries, the rest can draw } \\
\text { freshwater from sources and process in the plant. } \\
\text { Output: Organic compounds contributing to high BOD and COD, heavy } \\
\text { metals; Lesser scale: sedimentation. }\end{array}$ & $4 / 5$ industries are water-intensive \\
\hline MAL & $\begin{array}{l}\text { Input: High-quality water needed for only } 1 / 5 \text { industries, the rest can draw } \\
\text { freshwater from sources and process in the plant. } \\
\text { Output: Organic compounds contributing to high BOD and COD, Nitrogen, } \\
\text { Sulfates Lesser scale: phosphorus, sedimentation. }\end{array}$ & $3 / 5$ industries are water-intensive \\
\hline PHI & $\begin{array}{l}\text { Input: } 2 / 6 \text { top industries require high-quality water } \\
\text { Output: Heavy metals, Lesser scale: BOD and COD, sedimentation, oil and } \\
\text { grease }\end{array}$ & $4 / 6$ require high quantity of water \\
\hline VIE & $\begin{array}{c}\text { Input: Only one requires high-quality water } \\
\text { Output: Heavy metals, BOD and COD, Sedimentation, Lesser scale: cyanide, } \\
\text { acids, nitrogen, phosphorus, sulfates }\end{array}$ & $\begin{array}{l}\text { Almost all industries are } \\
\text { water-intensive }\end{array}$ \\
\hline
\end{tabular}




\section{References}

1. HV, V.; Thompson, F.; Tonby, O. Understanding ASEAN: Seven Things You Need to Know|McKinsey. Available online: https://www.mckinsey.com/industries/public-sector/our-insights/understanding-aseanseven-things-you-need-to-know (accessed on 22 August 2019).

2. ESCAP-UNISDR. Reducing Vulnerability and Exposure to Disasters 2012: The Asia-Pacific Disaster Report; ESCAP-UNSDIR: Bangkok, Thailand, 2012.

3. Xinhua Cambodia's Income Targets Are "Very Ambitious": World Bank Experts. Available online: http: //www.xinhuanet.com/english/2018-11/28/c_137637372.htm (accessed on 21 August 2019).

4. Office of the National Economic and Social Development Board. The Twelfth National Economic and Social Development Plan (2017-2021); Office of the Prime Minister: Bangkok, Thailand, 2017.

5. UN Water. Water Security \& the Global Water Agenda. The UN-Water Analytical Brief; United Nations University: Hamilton, Canada, 2013; ISBN 9788578110796.

6. Asian Development Bank. The Economics of Climate Change in Southeast Asia: A Regional Review; Asian Development Bank: Manila, Philippines, 2009.

7. Biswas, A.K.; Seetharam, K.E. Achieving Water Security for Asia. Int. J. Water Resour. Dev. 2008, 24, 145-176. [CrossRef]

8. $\quad$ Biggs, E.M.; Boruff, B.; Bruce, E.; Duncan, J.M.A.; Haworth, B.J.; Duce, S.; Horsley, J.; Curnow, J.; Neef, A.; Mcneill, K.; et al. Environmental Livelihood Security in Southeast Asia and Oceania A Water-Energy-Food-Livelihoods Nexus Approach for Spatially Assessing Change; International Water Management Institute: Colombo, Sri Lanka, 2014.

9. Asian Development Bank. Asian Water Development Outlook 2016: Strengthening Water Security in Asia and the Pacific; Asian Development Bank: Manila, Philippines, 2016.

10. S. Rajatnaram School of International Studies. Water Security Insights for An Urbanizing Southeast Asia; Centre for Non-Traditional Security Studies: Singapore, 2016.

11. Leichenko, R.; O'Brien, K. Environmental Change and Globalization Double Exposures; Oxford University Press: New York, NY, USA, 2008; ISBN 9780195177312.

12. Hjerpe, M.; Glaas, E. Evolving local climate adaptation strategies: Incorporating influences of socio-economic stress. Mitig. Adapt. Strateg. Glob. Chang. 2012, 17, 471-486. [CrossRef]

13. Okpara, U.T.; Stringer, L.C.; Dougill, A.J. Using a novel climate-water conflict vulnerability index to capture double exposures in Lake Chad. Reg. Environ. Chang. 2017, 17, 351-366. [CrossRef]

14. Hughes, S.; Pincetl, S.; Boone, C. Triple exposure: Regulatory, climatic, and political drivers of water management changes in the city of Los Angeles. Cities 2013, 32, 51-59. [CrossRef]

15. Lele, S.; Srinivasan, V.; Thomas, B.K.; Jamwal, P. Adapting to climate change in rapidly urbanizing river basins: Insights from a multiple-concerns, multiple-stressors, and multi-level approach. Water Int. 2018, 43, 281-304. [CrossRef]

16. Mason, L.R. Seasonal Water Insecurity in Urban Philippines: Examining the Role of Gender, Resources, and Context; Washington University in St. Louis: Washington, DC, USA, 2013.

17. Bennett, N.J.; Dearden, P.; Peredo, A.M. Vulnerability to multiple stressors in coastal communities: A study of the Andaman coast of Thailand. Clim. Dev. 2015, 7, 124-141. [CrossRef]

18. Herbeck, J.; Flitner, M. Infrastructuring coastal futures: Key trajectories in Southeast Asian megacities. J. Geogr. Soc. Berlin 2019, 150, 118-130.

19. World Bank. World Bank Country and Lending Groups-World Bank Data Help Desk. Available online: https://datahelpdesk.worldbank.org/knowledgebase/articles/906519-world-bank-country-andlending-groups (accessed on 15 November 2019).

20. Ly, S. Cambodia Is Now a Lower-Middle Income Economy: What Does This Mean? Available online: https://blogs.worldbank.org/eastasiapacific/cambodia-is-now-a-lower-middle-income-economywhat-does-this-mean (accessed on 20 August 2019).

21. World Bank. Lao PDR Now a Lower-Middle Income Economy. Available online: https://www. worldbank.org/en/news/press-release/2011/08/17/lao-pdr-now-lower-middle-income-economy (accessed on 20 August 2019). 
22. Reuters Bangladesh, Kenya, Myanmar move up Income Ranks-World Bank-Reuters. Available online: https://www.reuters.com/article/worldbank-income-upgrades/bangladesh-kenya-myanmar-moveup-income-ranks-world-bank-idUSL8N0ZI3SP20150702 (accessed on 20 August 2019).

23. United Nations. International Standard Industrial Classification of All Economic Activities (ISIC), Rev. 4; United Nations: New York, NY, USA, 2008.

24. World Bank. World Development Indicators. Available online: http://wdi.worldbank.org/table/4.2\# (accessed on 8 December 2019).

25. ASEAN. ASEAN Statistical Yearbook 2018; ASEAN Secretariat: Jakarta, Indonesia, 2018; ISBN 9786025798283.

26. Central Intelligence Agency The World Factbook 2019. Available online: https://www.cia.gov/library/ publications/resources/the-world-factbook/index.html (accessed on 23 August 2019).

27. Ngov, P.; Ngin, C. Cambodia's Economy and Its Services Sector in Global Value Chains: Cambodia's Economy and Its Services Sector in Global Value Chains; ERIA: Jakarta, Indonesia, 2019.

28. World Bank Group. Lao PDR Economic Monitor: Maintining Economic Stability; World Bank: Vientiane, Laos, 2019.

29. World Bank Group. Myanmar Economic Monitor June 2019; World Bank Group: Washington DC, WA, USA, 2019.

30. World Bank Group. Indonesia Economic Quarterly: Oceans of Opportunity; World Bank: Jakarta, Indonesia, 2019.

31. Malaysian Investment Development Authority Investment Data (Services Sector). Available online: https: //www.mida.gov.my/home/investment-data-(services-sector)/posts/ (accessed on 21 August 2019).

32. Mitra, R.M. Leveraging Service Sector Growth in the Philippines; ADB: Manila, Philippines, 2013; Volume 366.

33. NordeaTrade Thailand: Economic and Political Overview. Available online: https://www.nordeatrade.com/ fi/explore-new-market/thailand/economical-context (accessed on 21 August 2019).

34. OECD. Economic Outlook for Southeast Asia, China and India 2019; OECD Publishing: Paris, France, 2018.

35. United Nations. 2019 World Economic Situation and Prospects Report; United Nations: New York, NY, USA, 2019; ISBN 9789211091809.

36. Humphreys, D. In search of a new China: Mineral demand in South and Southeast Asia. Miner. Econ. 2018, 31, 103-112. [CrossRef]

37. Sophocleous, M. Interactions between groundwater and surface water: The state of the science. Hydrogeology 2002, 10, 52-67. [CrossRef]

38. WEPA. Outlook on Water Environmental Management in Asia; WEPA: Tokyo, Japan, 2018.

39. UNICEF; WHO. Progress on Household Drinking water, Sanitation and Hygiene 2000-2017. Special Focus on Inequalities; UNICEF: New York, NY, USA; WHO: New York, NY, USA, 2019.

40. Carrard, N.; Foster, T.; Willetts, J. Groundwater as a Source of Drinking Water in Southeast Asia and the Pacific: A Multi-Country Review of Current Reliance and Resource Concerns. Water 2019, 11, 1605. [CrossRef]

41. Jalilov, S.-M. Sustainable Urban Water Environments in Southeast Asia: Addressing the Pollution of Urban Waterbodies in Indonesia, the Philippines, and Viet Nam; United Nations University: Tokyo, Japan, 2016.

42. Hanada, Y. Southeast Asia looks for outside help to flush sewage problem. Nikkei Asian Rev. 2019. Available online: https:/asia.nikkei.com/Spotlight/Environment/Southeast-Asia-looks-for-outside-help-toflush-sewage-problems2context (accessed on 24 August 2019).

43. WSP. Improving On-site Sanitation and Connections to Sewers in Southeast Asia: Insights from Indonesia and Vietnam; World Bank: Washington, DC, USA, 2015.

44. Lerner, D.N.; Harris, B. The relationship between land use and groundwater resources and quality. Land Use Policy 2009, 26S, S265-S273. [CrossRef]

45. Chang, C.-P.; Wang, Z.; McBride, J.; Liu, C.-H.; Chang, C.-P.; Wang, Z.; McBride, J.; Liu, C.-H. Annual Cycle of Southeast Asia-Maritime Continent Rainfall and the Asymmetric Monsoon Transition. J. Clim. 2005, 18, 287-301. [CrossRef]

46. Kikuchi, K.; Wang, B.; Kajikawa, Y. Bimodal representation of the tropical intraseasonal oscillation. Clim. Dyn. 2012, 38, 1989-2000. [CrossRef]

47. Chang, C.-H. Preparedness and storm hazards in a global warming world: Lessons from Southeast Asia. Nat. Hazards 2011, 56, 667-679. [CrossRef]

48. Nguyen-Thi, H.A.; Matsumoto, J.; Ngo-Duc, T.; Endo, N. A climatological study of tropical cyclone rainfall in Vietnam. Sci. Online Lett. Atmos. 2012, 8, 41-44. [CrossRef] 
49. Kubota, H.; Wang, B. How Much Do Tropical Cyclones Affect Seasonal and Interannual Rainfall Variability over the Western North Pacific? J. Clim. 2009, 22, 5495-5510. [CrossRef]

50. Fritz, H.M.; Blount, C.D.; Thwin, S.; Thu, M.K.; Chan, N. Cyclone Nargis storm surge in Myanmar. Nat. Geosci. 2009, 2, 448-449. [CrossRef]

51. Université Catholique de Louvain (UCL); CRED; Guha-Sapir, D. EM-DAT: The Emergency Events Database. Available online: www.emdat.be (accessed on 20 August 2019).

52. Anshory Yusuf, A.; Francisco, H. Climate Change Vulnerability Mapping for Southeast Asia; EEPSEA: Singapore, 2009.

53. Chotamonsak, C.; Salathé, E.P.; Kreasuwan, J.; Chantara, S.; Siriwitayakorn, K. Projected climate change over Southeast Asia simulated using a WRF regional climate model. Atmos. Sci. Lett. 2011, 12, 213-219. [CrossRef]

54. Hijioka, Y.; Lin, E.; Pereira, J.J.; Corlett, R.T.; Cui, X.; Insarov, G.E.; Lasco, R.D.; Lindgren, E.; Surjan, A. Asia; Cambridge University Press: Cambridge, UK, 2014.

55. Hirabayashi, Y.; Mahendran, R.; Koirala, S.; Konoshima, L.; Yamazaki, D.; Watanabe, S.; Kim, H.; Kanae, S. Global flood risk under climate change. Nat. Clim. Chang. 2013, 3, 816-821. [CrossRef]

56. Van Vliet, M.T.; Franssen, W.H.; Yearsley, J.R.; Ludwig, F.; Haddeland, I.; Lettenamier, D.P.; Kabat, P. Global river discharge and water temperature under climate change. Glob. Environ. Chang. 2013, 23, 450-464. [CrossRef]

57. Van Vliet, M.T.H.; Zwolsman, J.J.G. Impact of summer droughts on the water quality of the Meuse river. J. Hydrol. 2008, 353, 1-17. [CrossRef]

58. Hoque, M.A.; D Scheelbeek, P.F.; Vineis, P.; Khan, A.E.; Ahmed, K.M.; Butler, A.P.; Hoque mhoque, M.A. Drinking water vulnerability to climate change and alternatives for adaptation in coastal South and South East Asia. Clim. Chang. 2016, 136, 247-263. [CrossRef] [PubMed]

59. Marcotullio, P.J. Urban water-related environmental transitions in Southeast Asia. Sustain. Sci. 2007, 2, 27-54. [CrossRef]

60. Freeman, P.; Warner, K. Vulnerability of Infrastructure to Climate Variability: How Does This Affect Infrastructure Lending Policies? World Bank: Washington, DC, USA, 2001.

61. Gopalakrishnan, C. Water and disasters: A review and analysis of policy aspects. Int. J. Water Resour. Dev. 2013, 29, 250-271. [CrossRef]

62. McCann, D.G.; Moore, A.; Walker, M.-E. The water/health nexus in Disaster Medicine. II: Water contamination in disasters. Curr. Opin. Environ. Sustain. 2011, 3, 486-490. [CrossRef]

63. Few, R.; Ahern, M.; Matthies, F.; Kovats, S. Floods, Health and Climate Change: A Strategic Review; Tyndall Centre: Norwich, UK, 2004.

64. Phanuwan, C.; Takizawa, S.; Oguma, K.; Katayama, H.; Yunika, A.; Ohgaki, S. Monitoring of human enteric viruses and coliform bacteria in waters after urban flood in Jakarta, Indonesia. Water Sci. Technol. 2006, 54, 203-210. [CrossRef]

65. Ramachandraiah, C. Coping with urban flooding: A study of the 2009 kurnool floods, India. Environ. Urban. 2011, 23, 431-446. [CrossRef]

66. Lyubimova, T.; Lepikhin, A.; Parshakova, Y.; Tiunov, A. The risk of river pollution due to washout from contaminated floodplain water bodies during periods of high magnitude floods. J. Hydrol. 2016, 534, 579-589. [CrossRef]

67. Marcotullio, P.J. Asian urban sustainability in the era of globalization. Habitat Int. 2001, 25, 577-598. [CrossRef]

68. Agrawala, S.; Carraro, M.; Kingsmill, N.; Lanzi, E.; Prudent-richard, G. Private Sector Engagement in Adaptation to Climate Change; OECD Publishing: Paris, France, 2011.

69. Magtibay, B.; Anarna, M.; Fernando, A. Assessment of drinking water post-Haiyan. West. Pacific Surveill. Response J. 2015, 6, 48-52. [CrossRef]

70. Hossain, J.; Salehin, M.; Mourin, M.M. Impact of Storm Surge Flooding on Groundwater Salinity in the Polder Protected and Non-Polder Area of Coastal Aquifer in Bangladesh. In Proceedings of the International Conference on Disaster Risk Mitigation, At BUET, Dhaka, Bangladesh, 23-24 September 2017.

71. Xiao, H.; Wang, D.; Medeiros, S.; Bilskie, M.; Hagen, S.; Hall, C. Exploration of the effects of storm surge on the extent of saltwater intrusion into the surficial aquifer in coastal east-central Florida (USA). Sci. Total Environ. 2019, 648, 1002-1017. [CrossRef] [PubMed] 
72. David, C.C.; Inocencio, A.B.; Clemente, R.S.; Abracosa, R.P.; Tabios, G.Q. Metro Manila and Metro Cebu Groundwater Assessment; National Center for Biotechnology Information: Makati City, Philippines, 2001.

73. Ngo, M.T.; Lee, J.M.; Lee, H.A.; Woo, N.C. The sustainability risk of Ho Chi Minh City, Vietnam, due to saltwater intrusion. Geosci. J. 2015, 19, 547-560. [CrossRef]

74. Benner, S.; Polizzotto, M.; Kocar, B.; Ganguly, S.; Phan, K.; Ouch, K.; Sampson, M.; Fendor, S. Groundwater flow in an arsenic-contaminated aquifer, Mekong Delta, Cambodia. Appl. Geochem. 2008, 23, 3072-3087. [CrossRef]

75. Alcamo, J.; Florke, M.; Marker, M. Future long-term changes in global water resources driven by socio-economic and climatic changes. Hydrol. Sci. J. 2007, 52, 247-275. [CrossRef]

76. Alayu, E.; Yirgu, Z. Advanced technologies for the treatment of wastewaters from agro-processing industries and cogeneration of by-products: A case of slaughterhouse, dairy and beverage industries. Int. J. Environ. Sci. Technol. 2018, 15, 1581-1596. [CrossRef]

77. Choudhary, M.P.; Gupta, D. Assessing Environmental Impacts of a Cement Industry during its Operation Phase. Int. J. Res. Sci. Innov. 2017, 4, 65-68.

78. Sharma, K.; Jain, U.; Singhal, A. Treatment of Waste Generated From Cement Industry and Their Treatment-A Review; BITS Pilani: Pilani, India, 2013.

79. Ellis, M.; Dillich, S.; Margolis, N. Industrial Water Use and Its Energy Implications; ACEEE: Tarrytown, NY, USA, 2001.

80. Bardhan, S. Assessment of water resource consumption in building construction in India. WIT Trans. Ecol. Environ. 2011, 144, 93-100.

81. Rahman, N.N.N.A.; Esa, N. Managing Construction Development Risks to the Environment. In Sustainable Living with Environmental Risks; Springer Japan: Tokyo, Japan, 2014; pp. 193-202.

82. McCormack, M.; Treloar, G.J.; Palmowski, L.; Crawford, R. Modelling direct and indirect water requirements of construction. Build. Res. Inf. 2007, 35, 156-162. [CrossRef]

83. Ooshaksaraie, L.; Basri, N.E.A.B. An Expert System Applied in Construction Water Quality Monitoring. Am. J. Environ. Sci. 2011, 7, 75-81. [CrossRef]

84. Milman, O. Most US Coal Plants Are Contaminating Groundwater with Toxins, Analysis Finds|Environment|The Guardian. Available online: https://www.theguardian.com/environment/2019/ mar/04/us-coal-plants-contaminating-groundwater-toxins-analysis (accessed on 25 August 2019).

85. Renöfält, B.M.; Jansson, R.; Nilsson, C. Effects of hydropower generation and opportunities for environmental flow management in Swedish riverine ecosystems. Freshw. Biol. 2010, 55, 49-67. [CrossRef]

86. Associated Press U.S. Utilities Find Water Pollution at Coal-Burning Power Plants-CBS News. Available online: https://www.cbsnews.com/news/u-s-utilities-find-water-pollution-at-coal-burning-power-plants/ (accessed on 25 August 2019).

87. Schleifer, L.; Luo, T. Power Plants Use Water, But We Have No Idea How Much|World Resources Institute. Available online: https://www.wri.org/blog/2018/01/power-plants-use-water-we-have-no-idea-how-much (accessed on 25 August 2019).

88. Tu, W.; Lee, Y. Ineffective environmental laws in regulating electronic manufacturing pollution: Examining water pollution disputes in Taiwan. In Proceedings of the 2009 IEEE International Symposium on Sustainable Systems and Technology, Phoenix, AZ, USA, 18-20 May 2009; pp. 1-6.

89. Abdel Wahaab, R.; Alseroury, F.A. Wastewater treatment: A case study of electronics manufacturing industry. Int. J. Environ. Sci. Technol. 2019, 16, 47-58. [CrossRef]

90. Chai, J.C.H. Trade and environment: Evidence from China's manufacturing sector. Sustain. Dev. 2002, 10, 25-35. [CrossRef]

91. Dong, H.; Geng, Y.; Sarkis, J.; Fujita, T.; Okadera, T.; Xue, B. Regional water footprint evaluation in China: A case of Liaoning. Sci. Total Environ. 2013, 442, 215-224. [CrossRef] [PubMed]

92. Rashmi, V.; Pratima, D. Heavy metal water pollution-A case study. Recent Res. Sci. Technol. 2013, 5, 98-99.

93. Gilde, L.C. Measures taken against water pollution in the food processing industry. Pure Appl. Chem. 1972, 29, 143-162. [CrossRef] [PubMed]

94. Herndon, L. Managing Water Impacts of NC Food Processing-Environmental Finance Blog. Available online: http://efc.web.unc.edu/2016/02/23/food-processing/ (accessed on 25 August 2019).

95. Valta, K.; Kosanovic, T.; Malamis, D.; Moustakas, K.; Loizidou, M. Overview of water usage and wastewater management in the food and beverage industry. Desalin. Water Treat. 2015, 53, 3335-3347. [CrossRef] 
96. EPA (Environmental Protection Agency Office of Water). Industrial Stormwater Fact Sheet Series Sector A: Timber Products; EPA: Washington, DC, USA, 2006.

97. Hedmark, Å.; Scholz, M. Review of environmental effects and treatment of runoff from storage and handling of wood. Bioresour. Technol. 2008, 99, 5997-6009. [CrossRef]

98. National Institute of Water and Atmospheric Research Impacts of Wood Processing. Available online: https://niwa.co.nz/our-science/freshwater/tools/kaitiaki_tools/land-use/foresry-processing/impactsof-forest-processing (accessed on 25 August 2019).

99. Statistics Canada Industrial Water Usage. Available online: https://www150.statcan.gc.ca/n1/pub/16-401-x/ 2012001/part-partie1-eng.htm (accessed on 25 August 2019).

100. Wu, P.; Jiang, L.Y.; He, Z.; Song, Y. Treatment of metallurgical industry wastewater for organic contaminant removal in China: Status, challenges, and perspectives. Environ. Sci. Water Res. Technol. 2017, 3, 1015-1031. [CrossRef]

101. Koumany, S. Water Quality and Monitoring in Lao PDR: The Case Study of Nam Ngum River Basin. In Proceedings of the 3rd WEPA Forum on Environmental Governance in Asia, Ministry of Environment Japan, Bangkok, Thailand, 14-15 March 2007; pp. 129-131.

102. Prosser, I.; Wolf, L.; Littleboy, A. Water in mining and industry. In Water: Science and Solutions for Australia; Commonwealth Scientific and Industrial Research Organisation: Canberra, Australia, 2011; pp. 135-146.

103. Ugya, A.Y.; Ajibade, F.O. Ajibade TF Water Pollution Resulting From Mining Activity: An Overview. In Proceedings of the 2018 Annual Conference of the School of Engineering \& Engineering Technology (SEET), The Federal University of Technology, Akure, Nigeria, 17-19 July 2018.

104. Gavrilescu, D.; Puitel, A.C.; Dutuc, G.; Craciun, G. Environmental impact of pulp and paper mills. Environ. Eng. Manag. J. 2012, 11, 81-85. [CrossRef]

105. Ince, B.K.; Cetecioglu, Z.; Ince, O. Pollution Prevention in the Pulp and Paper Industries. In Environmental Management in Practice; Broniewicz, E., Ed.; IntechOpen: Rijeka, Croatia, 2011; pp. 223-246.

106. Jung, H.; Kappen, J. Water in the paper industry: Current situation and future options. Prof. Papermak. 2014, 11,11-13.

107. Gadipelly, C.; Pérez-González, A.; Yadav, G.D.; Ortiz, I.; Ibáñez, R.; Rathod, V.K.; Marathe, K.V. Pharmaceutical Industry Wastewater: Review of the Technologies for Water Treatment and Reuse. Ind. Eng. Chem. Res. 2014, 53, 11571-11592. [CrossRef]

108. Jacobs Consultancy. Water Consumption in US Petroleum Refineries Final Report; Jacobs Consultancy: Chicago, IL, USA, 2016.

109. Girardi, A. Wastewater treatment and reuse in the oil \& petrochem industry-A case study. In Proceedings of the Wastewater and Biosolids Treatment and Reuse: Bridging Modeling and Experimental Studies, Otranto, Italy, 8-14 June 2014; Santoro, D., Ed.; ECI Symposium Series; Trojan Technologies and Western University: London, ON, Canada, 2014.

110. Hansen, É.; Rodrigues, M.A.S.; Aragão, M.E.; de Aquim, P.M. Water and wastewater minimization in a petrochemical industry through mathematical programming. J. Clean. Prod. 2018, 172, 1814-1822. [CrossRef]

111. Sivarajasekar, N.; Balasubramani, K. A short account on petrochemical industry effluent treatment. Int. J. Petrochemical Sci. Eng. 2018, 3. [CrossRef]

112. Mohammadi, M.; Man, H.; Hassan, M.; Yee, P. African Journal of Biotechnology. Acad. J. 2002, 9, 1-11.

113. Tanikawa, D. Commentary on Appropriate Wastewater Treatment System for a Natural Rubber Processing Factory. J. Microb. Biochem. Technol. 2017, 9, 159-161.

114. Leong, S.T.; Muttamara, S.; Laortanakul, P. Reutilization of wastewater in a rubber-based processing factory: A case study in Southern Thailand. Resour. Conserv. Recycl. 2003, 37, 159-172. [CrossRef]

115. Musikavong, C.; Gheewala, S.H. Water scarcity footprint of products from cooperative and large rubber sheet factories in southern Thailand. J. Clean. Prod. 2016, 134, 574-582. [CrossRef]

116. Bashar, A.K. Textile Manufacturing Process, Pollution and Pollution Control; Jahangirnagar University: Dhaka, Bangladesh, 2012.

117. Sakamoto, M.; Ahmed, T.; Begum, S.; Huq, H. Water Pollution and the Textile Industry in Bangladesh: Flawed Corporate Practices or Restrictive Opportunities? Sustainability 2019, 11, 1951. [CrossRef]

118. Tüfekci, N.; Sivri, N.; Toroz, İ. Pollutants of Textile Industry Wastewater and Assessment of its Discharge Limits by Water Quality Standards. Turkish J. Fish. Aquat. Sci. 2007, 7, 97-103. 
119. Das, P.; Mondal, G.C.; Singh, S.; Singh, A.K.; Prasad, B.; Singh, K.K. Effluent Treatment Technologies in the Iron and Steel Industry-A State of the Art Review. Water Environ. Res. 2018, 90, 395-408. [CrossRef]

120. Gandhirajan, M.; Amarnath, G.; Kavitha, P.; Bhagavath, R. Characterisation and Treatment of Automotive Industry Wastewater. J. Ind. Pollut. Control 2008, 24, 9-14.

121. Isaiah, D. Water, Water, Everywhere in Vehicle Manufacturing|Automotive World. Available online: https://www.automotiveworld.com/articles/water-water-everywhere-vehicle-manufacturing/ (accessed on 15 November 2019).

122. Mirbagheri, S. Optimization of Motor Vehicle Industries Wastewater Treatment Methods with the Aim of Heavy Metals Removal and Water Reuse in Pilot Scale. Iran. J. Environ. Health Sci. Eng. 2006, 3, $289-295$.

123. Toyota Motor Corporation. Environmental Report 2018; Toyota Motor Corporation: Toyota, Japan, 2018.

2019 by the authors. Licensee MDPI, Basel, Switzerland. This article is an open access article distributed under the terms and conditions of the Creative Commons Attribution (CC BY) license (http://creativecommons.org/licenses/by/4.0/). 